\title{
PERALIHAN HAK ATAS TANAH TERHADAP PROSES JUAL BELI
}

\author{
Atika Sandra Dewi, SH, MH \\ Universitas Amir Hamzah \\ Ikasandradewi1203@gmail.com
}

\begin{abstract}
Abstrak
Dari hasil penelitian menunjukan bahwa masih banyak masyarakat yang masih kurangnya pemahaman akan pentingnya pelaksanaan peralihan jual beli sehinggah masih ada jual beli dibawah tangan.Upaya badan pertanahan dalam menengani kendala dalam pelaksanaan peralihan hak atas tanah dalam bentuk jual beli yakni mengadakan penyuluhan tentan masalah pertanahan sebagai usaha menimbulkan kesadaran masyarakat betapa pentingnya sertifikat,penyuluhan merupakan jalan terbaik,karena pihak yang berwenang dalam hal ini kantor pertanahan dapat melakukan pendekatan secara langsung dari masyarakat,dengan adanya pendekatan dari kantor pertanahan menjadi positif sehingga dapat membantu proses pendaftaran dan persertifikatan. Berdasarkan kegunaan secara teoritis maka diharapkan dapat memberikan sumbangan saran dan pengetahuan dalam ilmu hukum khususnya dibidang hukum agraria, khususnya mengenai peralihan hak atas tanah dalam bentuk jual beli.
\end{abstract}

Kata kunci : Hak atas tanah, Proses jual beli

\section{PENDAHULUAN}

Tanah mempunyai kedudukan dan fungsi yang sangat penting dalam kehidupan manusia. Bagi manusia tanah merupakan tempat permukiman, tempat manusia melakukan kegiatan dan bahkan setelah meninggal.kebutuhan akan tanah semakin meningkat sejalan dengan bertambahnya jumlah penduduk dan meningkatkan kebutuhan lain yang berkaitan dengan sumber daya alam khususnya tanah. Karena tanah sebagian bagian dari bumi mempunyai fungsi yang sangat penting. Atas dasar ketentuan Pasal 33 Ayat (3) Undang- undang Dasar 1945 bumi,air,ruang angkasa,termasuk kekayaan alam yang terkndung di dalamnya itu pada tingkatan 
tertinggi dikuasai oleh Negara, sebagai organisasi kekuasaan seluruh rakyat Peralihan atau pemindahan hak adalah suatu perbuatan hukum yang bertujuan memindahkan hak dari suatu pihak ke pihak lain. Berbeda dengan dialihkannya suatu hak, maka dengan dialihkannya suatu hak menunjukkan adanya suatu perbuatan hukum yang disengaja dilakukan oleh satu pihak dengan maksud memindahkan hak miliknya kepada orang lain. Dengan demikian pemindahannya hak milik tersebut diketahui atau diinginkan oleh pihak yang melakukan perjanjian peralihan hak atas tanah. Jual beli tanah adalah perbuatan hukum yang berupa penyerahan Hak Milik (penyerahan tanah untuk selama-lamanya) oleh penjual kepada pembeli.yang pada saat itu juga pembeli menyerahkan harganya kepada penjual.jual yang mengakibatkan beralihnya hak milik atas tanah dari penjual kepada pembeli itu termasuk dalam hukum agraria dan hukum tanah.

\section{KAJIAN PUSTAKA}

Peralihan hak atas tanah merupakan salah satu peristiwa dan/atau perbuatan hukum yang mengakibatkan terjadinya pemindahan hak atas tanah dari pemilik kepada pihak lainnya. Peralihan tersebut bisa disengaja oleh karena adanya perbuatan hukum seperti jual beli, sewa-menyewa dan sebagainya, dan juga tidak disengaja karena adanya peristiwa hukum seperti peralihan hak karena warisan. ketentuan tersebut menjelaskan bahwa peralihan hak atas tanah adalah suatu peristiwa/perbuatan hukum yang mengakibatkan berpindahnya hak dari subyek hukum yang satu ke subyek hukum lainnya, sehingga menyebabkan kehilangan kewenangannya terhadap tanah tersebut.

Jual beli dalam bahasa Indonesia berasal dari dua kata, yaitu jual dan beli. Yang dimaksud dengan jual beli adalah berdagang, berniaga, menjual dan membeli barang. Menurut pasal 20 ayat 2 Kompilasi Hukum Ekonomi Syariah, ba ${ }^{e e}$ adalah jual beli antara benda dan benda, atau pertukaran antara benda dengan uang. Pengertian tersebut dapat dipahami bahwa jual beli menurut bahasa adalah tukar menukar apa saja, baik antara barang dengan barang, maupun dengan uang atau 
uang dengan uang. Dari beberapa definisi di atas dapat disimpulkan bahwa jual beli adalah aktifitas dimana seorang penjual menyerahkan barangnya kepada pembeli setelah keduanya bersepakat terhadap barang tersebut, kemudian pembeli menyerahkan sejumlah uang sebagai imbalan atas barang yang diterimanya, yang mana penyerahannya dilakukan oleh kedua belah pihak dengan didasarkan atas rela sama rela. Sehingga dapat dipahami bahwa pengertian jual beli adalah kesepakatan tukar menukar barang atau barang dengan uang yang dapat ditasharufkan, disertai pertukaran hak kepemilikan dari yang satu ke yang lain secara sukarela.

\section{DISCUSSION}

\section{Jual Beli Menurut Ketentuan Hukum Tanah Nasional}

Jual beli tanah dalam hukum Tanah Nasional melandaskan pada Hukum Adat. Peralihan hak atas tanah menurut ketentuan Pasal 37 Peraturan Pemerintah Nomor 24 Tahun 1997 tentang Pendaftaran Tanah (PP No. 24 Tahun 1997) dapat dilakukan dengan perbuatan hukum seperti jual beli, tukar menukar, hibah, pemasukan kedalam perusahaan dan perbuatan hukum lainnya yang dibuktikan dengan pembuatan akta yang dibuat dihadapan pejabat pembuat Akta Tanah (PPAT). Sebagai ketentuan formalnya atau mengenai bentuk, isi dan cara pembuatan akta peralihan hak atas tanah diatur dalam Peraturan Pemerintah No. 24 Tahun 1997 dan Peraturan Kepala Badan Pertanahan Nasional Nomor 1 tahun 2006 dan Peraturan Menteri Agraria/Kepala BPN Nomor 3 Tahun 1997. Dalam ketentuan Pasal 39 PP Nomor 24 Tahun 1997 disebutkan bahwa PPAT menolak membuat akta jika: a. Mengenai bidang tanah yang sudah terdaftar kepadanya tidak disampaikan sertipikat asli hak yang bersangkutan atau sertipikat yang diserahkan tidak sesuai dengan daftar yang ada di Kantor Pertanahan; b. Mengenai bidang tanah yang belum didaftar, kepadanya tidak disampaikan.

\section{Jual Beli Menurut Ketentuan Hukum Adat}

Bila ada kehendak yang disengaja dan disepakati atas sebidang tanah Hak Milik, maka didalamnya ada pengalihan hak atas tanah tersebut. Bila pengalihan tersebut 
dipaksakan oleh kewenangan dan kekuasaan Negara maka disebut dengan pencabutan hak dan inipun harus menempuh persyaratan sebab terjadinya pemutusan hubungan hukum kepemilikan hak atas tanah.(Yamin dan Rahim) Jual beli khususnya dengan objek tanah dalam Hukum Adat memberikan pengertian bahwa jual beli tanah bukan perbuatan hukum yang merupakan perjanjian obligatur namun berupa pemindahan hak dengan pembayaran tunai artinya harga yang disetujui bersama dibayar penuh pada saat dilakukan jual beli yang bersangkutan. Dalam Hukum Adat tidak dikenal adanya pengertian penyerahan secara yuridis sebagai pemenuhan kewajiban hukum Penjual karena justru apa yang disebut dengan jual beli tanah adalah penyerahan hak atas tanah yang dijual kepeda Pembeli yang pada saat yang sama membayar penuh kepada Penjual harga yang telah disetujui bersama. Peralihan hak atas tanah melalui jual beli mengandung pengertian yaitu perbuatan hukum pemindahan hak selama-lamanya dari si penjual kepada si pembeli dan pembayaran harga baik selurunya maupun sebagian dari pembeli dilakukan dengan syarat terang dan tunai. Syarat terang berarti bahwa perjanjian jual beli tersebut harus dilakukan dihadapan pejabat Adat yang berwenang dan disaksikan oleh dua orang saksi. Syarat tunai berarti adanya dua perbuatan yang dilakukan secara bersamaan yaitu pemindahan hak dari si penjual kepada si pembeli dan pembayaran harga baik sebagian maupun seluruhnya dari pembeli kepada penjual. Pembayaran harga jual beli bisa dibayarkan seluruhnya maupun sebagian.

\section{KESIMPULAN}

\section{Kesimpulan}

1. Pelaksanaan peralihan hak atas tanah dapat terjadi karena beralih atau dialihkan. Beralih, misalnya karena pewarisan. Sedangkan dialihkan misalnya atas dasar jual beli, tukar menukar, hibah, hibah wasiat dan perbuatan hukum pemindahan hak lainnya. Pembuktian bahwa hak atas tanah tersebut dialihkan, maka harus dibuktikan dengan suatu akta yang 
dibuat oleh dan dihadapan PPAT yaitu akta jual beli yang kemudian akan dijadikan dasar pendaftaran perubahan data pendaftaran tanah..

2. Kendala-kendala yang dihadapai masyarakat dalam pelaksanaan peralihan hak atas tanah dalam bentuk jual beli, seperti: 1 . Masih adanya pengisian jual beli oleh Pejabat Pembuat Akta Tanah (PPAT) yang kurang lengkap, kurang teliti dan cenderung tidak sempurna, tidak dilakukan pencoretan pada setiap perubahan atau penambahan tidak diparaf oleh Pejabat Pembuat Akta Tanah (PPAT), tidak dicap stempel oleh oleh Pejabat Pembuat Akta Tanah (PPAT). 2. Masih adanya berkas yang belum lengkap, foto copy Kartu Tanda Penduduk (KTP) yang tidak berlaku belum dilegalisir oleh pejabat yang berwenang. 3. Tanah yang dijual beli masih dalam sengketa 4. Kurangnya pemahaman masyarakat akan pentingnya pelaksanaan peralihan jual beli sehingga masih ada jual beli di bawah tangan 5. Jual beli dianggap sah oleh masyarakat walaupun jual beli tanpa didaftarkan di BPN setempat. 6. Kurang kesadaran hukum dari masyarakat itu sendiri mengenai arti dan pentingnya pendaftaran tanah. 7 . Kondisi ekonomi masyarakat yang masih rendah 8. Kurangnya surat bukti pemilikan tanah.

\section{Saran}

1. Adanya sosialisasi tentang Hukum Tanah, khususnya dalam hal pelaksanaan peralihan hak atas tanah kepada masyarakat dan hendaknya aparat kantor pertanahan diharapkan membantu masyarakat yaitu dengan memberikan pelayanan yang sebaik-baiknya sesuai dengan kebutuhan serta perlunya tenaga yang professional baik teknis maupun administrasi sehingga dalam melayani masyarakat dapat dilakukan secara cepat, akurat dan professional.

2. Perlu adanya peraturan yang tegas mengenai batas waktu pelaksanaan peralihan hak atas tanah hak milik dalam bentuk jual beli dan sanksi bagi pihak yang tidak melaksanakannya. 


\section{REFERENCES}

\section{BUKU}

Ahmadi Rulan, 2014, Metodologi Penelitian Kualitatif, AR-Ruzz Media: Yogyakarta.

Ashshofa Burhan, 2007, Metode Penelitian Hukum, PT. Rineke Cipta:Jakarta. Chomzah Ali Achamad, 2002, Hukum Pertanahan Prestasi Pustaka : Jakarta. Gunawan Widjaja \& Kartini mulyadi,2004,Jual beli, PT raja grafindo persada: Jakarta

Kartini muljadi \& Gunawan widjaja,2004,Hak-Hak Atas Tanah , kharisma putra utama Salim,2001,Pengantar Hukum Perdata Tertulis (BW),sinar grafika:yogyakarta

Santoso urip, 2010,Pendaftaran dan Peralihan hak atas tanah, kecana prenadamedia group : jakarta

Soimin Soedharyo,2008, Status Hak Dan Pembebasan Tanah, Sinar Grafika: Jakarta

Sutedi Adrian,2014, Peralihan hak atas tanah dan pendaftrannya Sinar grafari: Jakarta

Sunggono Bambang, 2011, Meteode Penelitian Hukum, PT RajaGrafindo Persada Jakarta.

R.Murjiyanto \& Erna sri wibawa, 2013, hak atas tanah \& peralihannya,Liberty Yogyakarta

\section{PERATURAN PERUNDANG-UNDANGAN}

Undang-Undang Dasar Negara Republik Indonesia Tahun 1945

Undang-undang Pokok Agraria Nomor 5 Tahun 1960 Tentang Peraturan pokokpokok agraria

Peratura Pemerintah No 24 Tahun 1997 Tentang Pendaftaran Tanah 